\title{
Health, Law and Sexuality. Qui Cherche Trouve.
}

By The Hon. Michael Kirby AC CMG (Justice of the High Court of Australia (1996-2009); President of the Court of Appeal of Solomon Islands (1995-96); President of the New South Wales Court of Appeal (1984-96); Judge of the Federal Court of Australia (1983-4); Chairman of the Australian Law Reform Commission (1975-83); Deputy President of the Australian Conciliation and Arbitration Commission (1975-83). At present, he is Honorary Professor at La Trobe University Law School.)

La Trobe University, Melbourne, Australia

\begin{abstract}
This is the keynote address for the Bold Thinking Series event at the National Gallery of Victoria (NGV) Great Hall on 4 May 2017. The language of the oral delivery of this address has been retained. Amidst a rich historical context, the author explores the legal and moral complexities that lie at the intersection of law, sexuality and health. Drawing on his long-standing participation in many international bodies concerned with human rights, he discusses the many great wrongs perpetrated against LGTBQI communities both internationally and domestically, and highlights the challenges that countries around the world face to remove discrimination in laws, policies and culture. He emphasises by way of case examples, the physical, emotional and political harm that this has caused and will continue to cause if legislative and cultural change is not forthcoming. He concludes that equality before the law is a basic tenet of human rights, and that to the extent that Australia and other countries are not achieving equality, we must rise to the challenge and drive genuine change.

Keywords - Sexuality, Human Rights, LGTBQI, Equality, Homosexuality, La Trobe Law School, La Trobe Centre for Health, Law and Society
\end{abstract}

Acknowledgements. The author acknowledges work done on editing this text by Mira Stammers.

Disclosure statement - No potential conflict of interest was reported by the author.

License - This work is under Attribution-NonCommercial-ShareAlike 4.0 International (CC BY-NC-SA 4.0) https://creativecommons.org/licenses/by-nc-sa/4.0/ Suggested citation: The Hon. Michael Kirby AC CMG, “Health, Law and Sexuality. Qui Cherche Trouve." Law in Context, 36 (2): 5-9. DOI: https://doi.org/10.26826/ law-in-context.v36i2.105

\section{Summary}

1. Hatred and sexual minorities

2. Lifting our voices

3. References 


\section{HATRED AND SEXUAL MINORITIES}

Thank you for convening this event tonight in this most splendid hall of Australia. Look up at the ceiling of Leonard French. The wonderful colour. The beautiful panels. The whole atmosphere is just wonderful. I've had the privilege of being here on a number of occasions. But there is no doubt on the part of Sydneysiders ${ }^{1}$, we have got to admit, you've got it all over us so far as this wonderful venue is concerned. And beyond the venue, the wonders of art and the world of the spirit. Qui cherche trouve. That's the motto of La Trobe University ${ }^{2}$. It's a motto in the French language, ancient French. It means those who search will find. It's a good motto for a university. It is what a university should be about.

Searching and finding the truth. Reason and science. Rationality with consciousness. Rationality is the wonder of being alive. It's the wonder of being a human who is alive. And to have the privilege here tonight of having friends from the East China Normal University and other friends from overseas. I know that there are also friends here from other Australian universities who have come to join in La Trobe's celebration. So from all of us fellow citizens, thank you for being here tonight. Qui cherche trouve.

I was there not long after the establishment of La Trobe ${ }^{3}$. At the time I was an extremely troublesome student politician. There were a lot of us in those days. One of them was a young Gareth Evans, president of the Melbourne Students' Representative Council (SRC). I was president of the Sydney SRC and we would have our August conference of NUAUS ${ }^{4}$ in Melbourne. So I came here in that capacity in 1964, the year when the committee was established on the initiative of Robert Menzies, who did wonderful things for education and university education in particular. He gave many of us opportunities we otherwise wouldn't have had. And at that time the idea of the third university in Melbourne was accepted. But it was to be a university that was going to be a little bit different. It was going to look at things from a different angle. And so it did, including in my own discipline, the law.

At first, La Trobe didn't establish a Law School. It established a Department of Legal Studies. Its purpose was to stand outside the law and to question things which the law basically didn't question. To question the way judges saw the law. Or for that matter, the way parliaments accepted the law. And to try to improve law where that was justified. And to justify the improvements that were put forward. Qui cherche trouve. I thought it was a pretty good idea at the time. I knew the early people who were involved in the Department of Legal Studies, including Professor Kingston Braybrooke ${ }^{5}$. And my own old teacher at the University of Sydney, Professor Tony Blackshield ${ }^{6}$, who came down here to examine law from a realist point of view. The legal realists' point of view, had been taught in his Department in the Sydney Law School by Professor Julius Stone ${ }^{7}$, a great law teacher.

And so in 1964, La Trobe began its journey ${ }^{8}$. In 1967 the Victorian Premier, Sir Henry Bolte, in the presence of Sir Robert Menzies, laid the foundation stone. He urged that the university should be a university which would look at things slightly differently. Certainly, the Australian Research Centre in Sex, Health and Society (ARCSHS) has looked at things in a different way and from a different angle and indeed at a different subject ${ }^{9}$. In most of the countries back in 1964 to 67, nobody talked about these issues. Rational examination of a matter as intimate and

\footnotetext{
1 'Sydneysider' refers to a native or inhabitant of Sydney. To be contrasted with 'Melbournite'.

${ }^{2}$ La Trobe University was named after the first Lieutenant-Governor of Victoria, Charles Joseph La Trobe (1801-1875). He was born in London, but the origins of the family are found in Montauban, in the South of France. The patronymic "Qui cherche trouve" is the French translation of its first expression in the old Occitan language (langue d'oc): Qui la tròba, la cèrca. Cfr. Latrobe (2010) and Latrobe and Latrobe (2010).

${ }^{3}$ La Trobe University, Melbourne Campus, was established on 9 December 1964.

${ }^{4}$ National Union of Australian University Students. Established in the 1930s, the National Union of Australian University Students became the Australian Union of Students in 1971, see People and Organisations, National Library of Australia (Web Page) <https://trove.nla.gov.au/people/509485?c=people>.

${ }^{5}$ Professor Braybrooke (1915-1989) was a lawyer, civil servant and academic prior to his appointment at La Trobe University in 1971. He designed an innovative undergraduate program with a key focus in first year on Legal Studies, which he taught.

${ }^{6}$ Cfr. Kirby (2013). Professor Blackshield was Professor of Legal Studies (and sometime Head of Department) at La Trobe University from 1979 to 1988 . See also Petersen (2013).

${ }^{7}$ Professor Julius Stone (1907-1985) was Challis Professor of Jurisprudence and International Law at the University of Sydney from 1942 to 1972 , and thereafter a visiting Professor of Law at the University of New South Wales and concurrently Distinguished Professor of Jurisprudence and International Law at the Hastings College of Law, University of California. He authored thirty-seven books on jurisprudence and international law, and is hailed by his official biography at the Julius Stone Institute of Jurisprudence as one of the premier legal theorists.

${ }^{8}$ See Watson (2017), Fifty Years of La Trobe University.

${ }^{9}$ The ARCSHS was established in 1993 and is located within the College of Science, Health and Engineering at La Trobe University. It is a centre for social research into sexuality, health and the social dimensions of human relationships. It works collaboratively and in partnership with communities, community-based organisations, government and professionals in relevant fields to produce research that advances knowledge and promotes positive change in policy, practice and people's lives. See La Trobe University (Web Page) https://www.latrobe.edu.au/arcshs/about.
} 
private as sex was really not appropriate in polite circles. Even polite university circles.

And so La Trobe University began its journey and its journey included, in due course, a wonderful Law School and a wonderful Australian Research Centre in Sex, Health and Society. And I'm very proud to be here to help celebrate them both and all the achievements of La Trobe. The Vice Chancellor claims it is $\mathbf{5 0}$ years. This is the way Vice Chancellors operate. They are very clever with figures you see. He puts the 50 for La Trobe, plus the 25 for law and the 25 for the Research Centre, and claims a hundred. But I don't mind a hundred. It will be a hundred one day. But meantime at 50, it's quite an achievement. And it's a good occasion for us to get together and have a talk about something serious. This is what I'm going to now do.

Back in 1969, I was obeying a rule that was then required in Australian society. I was obeying the rule of doing nothing about the urgent messages of sexual orientation that were coming to me. But Qui cherche trouve prevailed. In 1969 I found my partner Johan van Vloten. He's up in Sydney tonight. I said, why don't you come down there? Melbourne people are really quite nice. But he said, no, you get on with it. I've heard all your speeches, so many times. But back in 1969 we observed the rule that when I telephoned him, I would let the phone ring twice and put it down and start again and ring again. Only then would he pick up the telephone. That procedure was required because we were told by law and by religion and by society that we had to be thoroughly ashamed of ourselves. And to keep our relationship all very secret and all to ourselves.

But then, a terrible tragedy struck. I refer to the advent of the AIDS epidemic in the 1980s. I became involved in international committees. Johan became an Ankali, which is a kind of buddy looking after people who were living with AIDS in Sydney. And so suddenly, because of a crisis in health, our secret lives seemed to take on a bigger dimension. Truth became rather more important than the requirements of secrecy. And we began to be much more open about the realities and the truth about our lives. This was because if you search, you'll find the truth. And the truth will set you free.

At that time, I began to be involved in work of United Nations committees tackling AIDS and human rights. I went to Jamaica. Terrible things happened in Jamaica. Terrible things have happened quite recently in Jamaica. But in the 1990s, a prison governor, seeking to reduce the spread of HIV in his prison, began to leave condoms in the prison and began also to leave bleach in the prison for the use of those who had needles and were using them in the prison compound. The prisoners didn't worry about the bleach. But they were very insulted by the condoms. That was suggesting that they were having sex with each other, which of course some were. But it was treated as a terrible insult to them. And so they rioted. They objected. The prison governor locked the jail up. He retreated. The prisoners grasped those whom they suspected to be gay. They led them into a cell, bound them and set the bedding on fire. They burned them to death. The riot was filled with the screams of their fellow prisoners. They'd locked them in the cell, and they burned them to death. You've got to really hate somebody to do a thing like that.

When, more recently, I went there to try to persuade the United Nations Development Programme and the Government of Jamaica to get rid of the law that they had, which is still enforced in most of the countries of the old British Empire now the Commonwealth of Nations, I urged them to get rid of that law as a start to reaching out, respecting and protecting the people who were at the greatest risk of HIV. I was told of the case of Dwayne Jones. Dwayne Jones was a young person in Montego Bay. He was in a process of transitioning from male to female. And he made the terrible mistake for Jamaica to go to the local discotheque attired in a dress.

Dwayne Jones was immediately assaulted. He was stabbed. He was bludgeoned. He was knocked to the ground. He was kicked. A car was ridden over him. He ultimately succumbed and died. His last words were: 'I am a girl'. You've got to really hate somebody to do so much to them. But Dwayne's parents wouldn't claim the body. They were so ashamed of Dwayne. So, these are the images that come back to my mind when I'm asked to speak at the anniversary of the Australian Research Centre in Sex, Health and Society. We don't now do things quite as horrible to gays in Australia as they do in Jamaica. This must be stopped everywhere. If we search, we will find the ways to make change happen. But terrible things are still happening in our country and in the world.

Last week I was in Bangkok for a conference of the Asia Pacific Forum. We were looking at how on earth they can get rid of the laws in the Asia Pacific countries, which still criminalize people who identify as gay, lesbian, bisexual, or transgender. How can they change the laws? At that meeting, one of the representatives was from Bangladesh. She rose in the conference. She said, 'You've probably heard of the case in Dhaka of the two young gay men who were bold enough to begin setting up a newsletter for the LGBT community in Dhaka. Their courage became known. Dhaka is a hostile place, if you are gay. The two young men were given jobs in the American Embassy. This was to the credit of the American Embassy. It was done in the hope of cloaking them with a degree of protection. But it didn't work.

In April 2016, there was a knock on the door where the newsletter was printed. "Couriers". They opened the door 
expecting to receive a courier. However, six men rushed in. They hacked the two gay men to death. And the leader of civil society in Bangladesh read a statement that had been made by the LGBT community in Bangladesh:

We're still hopeful to see that one-day newspapers will be publishing the news of those murderers. They were terrorists who were responsible for killing our friends. Society in the future will be supporting this minority. Our friends were just living human beings. Their families deserve justice for losing their sons so early in their lives and in this inhuman way. We also hope that news media will be less brutal and judgmental. We can only hope that our society will be more supportive. That it will not give them questionable looks every time they see them because their son was gay and was working for LGBT activism in Bangladesh. We have faith in all religions. We believe that religions are for peace in this world. Killing someone like this was never the intention of religion.

Also at the Bangkok conference, we were told that just two days earlier in Malé, Maldives, David was murdered. He was a journalist who had been generous and supportive in reporting the cruel conditions in the Maldives for LGBT citizens. He was in his home and he was also interrupted and hacked to death. This was just a week earlier. This is not ancient history. This is what is happening in our world, in the here and now. It is intolerable. It's bad for health. It's bad for citizenship. It's bad for science. It has to be changed.

But are we perfect in Australia? No, we're not. In the last year we witnessed a proposal in respect of the marriage issue for LGBT people that they should be subject to a plebiscite ${ }^{10}$. A referendum was constitutionally necessary when Aboriginal advancement was achieved. But it was not essential when advancement for the position of women in the law was achieved. It was not required when changes were made for disability discrimination. Nor to get rid of the White Australia Policy. It was just saved up to put it in position as an obstacle that the LGBT community of this country had to jump. It was done because there are still people here in Australia who hate the gay minority. They have considerable power and influence. They wanted to make it difficult to secure the facility of marriage for LGBT people.
Well, fortunately the Senate didn't approve of the plebiscite ${ }^{11}$ It did not agree to impose such a requirement as the deal that has been done to follow up the rights of equality for LGBT citizens in this country. That right now exists in 25 other countries with legal systems rather similar to our own. Of course, this is not an issue that burns in my heart. I've been with my partner Johan for 48 years. It has been 48 years of support, love and wisdom. It's very good for your health. It's very good for your mental health. If you can find such a partner, straight or gay, you're a very lucky human being. But it is denied in this country.

And so the question is, why is this so? Why the murders in beautiful Jamaica? Why the murders in Dhaka and in the Maldives and in other places? Why the deep feelings of hostility? I tried to work out these questions in my brain. They are the sort of questions that the Research Centre can address itself to ask people with power. Why are you being so cruel and nasty to people? After all it is just a little variation, which you should just get over? It's part of nature. Amongst, the reasons that I've thought of are that some people just have had limited experience with LGBT people. Well that excuse is getting a bit long in the tooth now. People have known about the issue of sexuality for quite a while. Of course, some people are just conservative. Well that's okay. I'm a bit conservative on some things myself. But on the matter of basic rights of equality under the law for all citizens, there's a place for action when equality is denied.

Of course, some people are religious. I am a bit religious myself. But I agree with what the leaders in Bangladesh said about religion. True religion is not an enemy to people's health, their lives and their dignity as human beings. Some people say, 'It's our culture'. Well, if this is so the 'culture' has to accept change in culture. Ban Ki-moon always said when he was UN Secretary-General, 'what's your problem?' The Universal Declaration of Human Rights says in Article $1^{12}$, "All persons are free and equal in dignity and rights". What's your problem with 'all persons'? All persons include LGBTI people.' Maybe it's repulsion at the very thought. Some people say natural law stands against the equality of relationship recognition.

Some say it's an aesthetic sense they don't like the look of [it]. Some say that they just feel uncomfortable, inferentially guided by personal demons. Well, get over it. Personal demons

\footnotetext{
${ }^{10}$ Unlike referenda which seek to change the Constitution and are binding on the government, plebiscites do not consider Constitutional questions nor do they bind the government. Instead, they focus on issues on which the government seeks approval to act or not to act.

${ }^{11}$ As an alternative to a plebiscite, the Australian Marriage Law Postal Survey was conducted in 2017 and was a national survey designed to gauge support for legalising same-sex marriage in Australia. Responding to the survey was voluntary and the survey results did not bind the government to introduce Constitutional or legislative change. National survey results concluded that all State and Territory jurisdictions had above $60 \%$ support for same-sex marriage.

${ }^{12}$ The exact text of Article 1 states 'All persons are born free and equal in dignity and rights. They are endowed with reason and conscience and should act towards one another in a spirit of brotherhood.', see Universal Declaration of Human Rights, GA Res 217A (III), UN GAOR, UN Doc A/810 (10 December 1948).
} 
need to be adjusted to the fundamental principle of the equality of all citizens, straight or gay.

\section{LIFTING OUR VOICES}

Qui cherche trouve. We must celebrate tonight the work of the Australian Research Centre in Sex, Health and Society. It is trying to do something that the enemies of equality want to repress or prevent. It is trying to establish our actions and our policies on sound social data. In the earliest days of the AIDS epidemic we resolved, and we followed it up in Australia, that we would rest our policies and strategies on sound data. Not on demons or myths or religious texts or irrational hatred.

We took this moral injunction seriously. As a nation, we began to do what the data suggested we should. We reached out. We did brave and bold things. We provided needle exchange in pharmacies across our continental country. The result was that we have one of the lowest levels of HIV in the whole world ${ }^{13}$, New Zealand and Australia because we provided needle exchange out of love for other people. And this is what is needed in Jamaica, Bangladesh, in Maldives, and in Australia.

The leader of the Human Rights Commission in Bangladesh asked me a question: 'How can we possibly get change in our country?' And I said, 'When I was growing up, there was a similar hatred in Australia. There was a lot of violence in Australia. But we got better'. 'And how did you get better?'. 'We got better in the same way as earlier, we got better on White Australia. We began to know Asian Australians. So, we began to know gay people. We began to know people of different race and different religion. We began to get used to human diversity. And even eventually to rather like it'.

When I was out at La Trobe main campus today, I was really impressed that the campus appears as a microcosm of the variety of Australia today. This is so different from 1964 when I was still at university! But the change has been good for Australia. Good for our economy and good for our universities. Good for the people in their millions. So, Qui cherche trouve. I think that's a good motto for a university. And it's a good injunction for this occasion. No more hatred. No more hostility. No more cruelty. It's against fundamental human rights. It's against people's right to health. It's against their right to mental health. And it's against, the equality of citizens in a country that should boast of equality. To the extent that we are not achieving it in Australia, we must get to and change things. To the extent that our neighbours and countries in the world are not achieving it, we must strive to help them.

We Australians must be concerned about that challenge. We must lift our voices about it. We must help those who need help. We must do research that helps them. We must bring the research to the notice of our own people. And we must help to change the world. It can be done. It will be done at a greater speed than it's been done in the past. The future starts here. It depends on us. Qui cherche trouve.

\section{REFERENCES}

1. Bartie, S. 2010. "A full day's work: a study of Australia's first legal scholarly community". University of Queensland Law Journal 29 (1): 67-100.

2. King, J. et al. 2018. HIV in Australia: Annual Surveillance Short Report, The Kirby Institute for infection and immunity in society, Sydney, https://kirby.unsw.edu.au/sites/default/ files/kirby/report/supplHIV2018_content_20180920r.pdf

3. Kirby, M., 2013. "AR Blackshield and Realism in Australian Constitutional Law". Inaugural Tony Blackshield Lecture. Macquarie Law Journal 11: 7-22.

4. Latrobe, P. 2010. "The Patronymic: The Latrobe/La Trobe Family Name." La Trobeana. Journal of the C. J. La Trobe Society Inc., 9 (2): 2, July, http://www.latrobesociety.org. au/LaTrobeana/LaTrobeanaV9n2.pdf

5. Latrobe, P. and Latrobe, J. 2010. "Looking for Ancestors: the origins of the Latrobe/La Trobe family.", La Trobeana. Journal of the C. J. La Trobe Society Inc., 9 (2): 3-7, July, http://www.latrobesociety.org.au/LaTrobeana/LaTrobeanaV9n2.pdf

6. Petersen, K. (Ed.). 2013. Law in Context 36 (2) Special Issue. Socio-legality: An Odyssey of Ideas and Context.

7. Watson, D., Manne, R., Altman, D., Wright, C., Anderson, M., and Davies, P. 2017. From the Paddock to the Agora: Fifty Years of La Trobe University. Melbourne: La Trobe University Press in conjunction with Black Inc.

\footnotetext{
${ }^{13}$ The estimated HIV prevalence in Australia in 2017 was $0.14 \%$ among adults aged older than 15 years. The prevalence in Australia is low compared to that reported to UNAIDS by other high-income countries including the United Kingdom ( $0.22 \%$ in 2016$)$, the United States $(0.42 \%$ in 2015$)$. See King et al. (2018, 41).
} 